\title{
4-Hydroxyestradiol induces mammary epithelial cell transformation through Nrf2-mediated heme oxygenase-1 overexpression
}

This article has been corrected. Correction in: Oncotarget. 2019; 10:1266-1266.

\section{Sin-Aye Park ${ }^{1}$, Mee-Hyun Lee ${ }^{1}$, Hye-Kyung Na ${ }^{4}$, Young-Joon Surh ${ }^{1,2,3}$}

${ }^{1}$ Research Institute of Pharmaceutical Sciences, Seoul National University, Seoul 08826, South Korea

${ }^{2}$ Department of Molecular Medicine and Biopharmaceutical Sciences, Graduate School of Convergence Science and Technology, Seoul National University, Seoul 08826, South Korea

${ }^{3}$ Cancer Research Institute, Seoul National University, Seoul 110-799, South Korea

${ }^{4}$ Department of Food and Nutrition, College of Human Ecology, Sungshin Women's University, Seoul 136-742, South Korea

Correspondence to: Young-Joon Surh, email: surh@ snu.ac.kr

Keywords: 4-hydroxyestradiol, heme oxygenase-1, catechol estrogen, Nrf2, breast cancer

Received: January 25, 2016

Accepted: May 12, 2016

Published: July 09, 2016

\section{ABSTRACT}

Estrogen ( $17 \beta$-estradiol, $E_{2}$ ) undergoes oxidative metabolism by CYP1B1 to form 4-hydroxyestradiol (4-OHE $)_{2}$, a putative carcinogenic metabolite of estrogen. Our previous study showed that 4- $\mathrm{OHE}_{2}$-induced production of reactive oxygen species contributed to neoplastic transformation of human breast epithelial (MCF-10A) cells. In this study, 4- $\mathrm{OHE}_{2}$, but not $\mathrm{E}_{2}$, increased the expression of heme oxygenase-1 (HO-1), a sensor and regulator of oxidative stress, in MCF-10A cells. Silencing the HO-1 gene

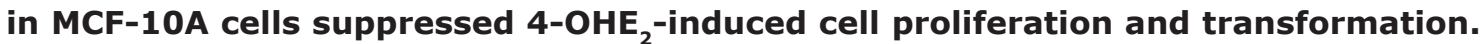
In addition, subcutaneous administration of $4-\mathrm{OHE}_{2}$ markedly enhanced the growth of the MDA-MB-231 human breast cancer xenografts, which was retarded by zinc protoporphyrin, a pharmacological inhibitor of $\mathrm{HO}-1$. 4-OHE ${ }_{2}$-induced $\mathrm{HO}-1$ expression was mediated by NF-E2-related factor 2 (Nrf2). We speculate that an electrophilic quinone formed as a consequence of oxidation of $4-\mathrm{OHE}_{2}$ binds directly to Kelch-like ECH-associated protein 1 (Keap1), an inhibitory protein that sequesters Nrf2 in the cytoplasm. This will diminish association between $\mathrm{Nrf2}$ and Keap1. 4-OHE ${ }_{2}$ failed to interrupt the interaction between Keap1 and Nrf2 and to induce HO-1 expression in Keap1-C273S or C288S mutant cells. Lano-LC-ESI-MS/MS analysis in MCF-10AKeap1-WT cells which were treated with $4-\mathrm{OHE}_{2}$ revealed that the peptide fragment containing Cys288 gained a molecular mass of 287.15 Da, equivalent to the addition of a single molecule of $4-\mathrm{OHE}_{2}$-derived ortho-quinones.

\section{INTRODUCTION}

4-Hydroxyestradiol (4-OHE $)$, an oxidized metabolite of $17 \beta$-estradiol $\left(\mathrm{E}_{2}\right)$, is detected at considerably high levels in human breast tumors $[1,2]$. This catechol estrogen has been proposed to contribute to hormonal carcinogenesis $[3,4] .4-\mathrm{OHE}_{2}$ with a catechol structure readily undergoes oxidation to electrophilic estradiol-3,4-quinone that can react with DNA to form depurinating adducts. Thus, estradiol-3,4-quinone may be an endogenous tumor initiator of mammary carcinogenesis [5-7]. The higher urinary levels of depurinating adducts derived from the 4-hydroxylated metabolite of estradiol were observed in women with breast cancer than in control subjects [8]. However, genotoxicity is not enough to complete the carcinogenic process, and the mechanisms underlying $4-\mathrm{OHE}_{2}$-induced mammary carcinogenesis still remains poorly understood. In our previous study, reactive oxygen species (ROS) generated through redox cycling of 4-OHE ${ }_{2}$ induced the transformation of human breast epithelial (MCF-10A) cells [9]. Notably, ROS-mediated activation of the IкB kinase-NF- $\kappa \mathrm{B}$ axis was found to be responsible for the transformation of these cells [9].

Heme oxygenase (HO) catalyzes degradation of heme to carbon monoxide, biliverdin, and free iron. Among three $\mathrm{HO}$ isoforms (HO-1, HO-2, and HO-3), HO-1 is the only inducible enzyme that plays a critical role in the cytoprotection against oxidative stress, inflammation, and other noxious stimuli [10-12]. 
However, the abnormally elevated expression and activity of this enzyme have been often reported in several tumor tissues, which may influence cancer cell proliferation, invasion and metastasis. In line with this notion, the overexpression of HO-1 enhanced viability, proliferation, and metastatic potential of melanoma cells [13]. HO-1 also stimulates angiogenesis through upregulation of vascular endothelial growth factor and overproduction of pro-angiogenic carbon monoxide [14]. Overexpression of HO-1 is detectable in biopsy tissues from oral AIDSKaposi sarcoma lesions [15] and advanced human prostate cancer tissues [16]. Moreover, pharmacological inhibitors of HO-1 have anti-carcinogenic effects in several tumor models $[17,18]$.

The transcription factor NF-E2-related factor 2 (Nrf2) regulates expression of genes encoding carcinogen detoxifying or antioxidative enzymes including HO-1 [19]. Nrf2 is present as an inactive complex in the cytoplasm with Kelch-like ECH-associated protein 1 (Keap1). One of the most plausible mechanisms responsible for $\mathrm{Nrf2}$ activation involves modification of specific Keap1 cysteine residues [20]. This facilitates the liberation of Nrf2 from Keap1 and subsequently nuclear translocation, leading to induction of the antioxidant/ electrophile responsive element (ARE/EpRE)-dependent target gene transcription. It is speculated that electrophilic quinones can activate Nrf2 by directly interacting with cysteine thiols of Keap1 [21, 22]. Sumi and colleagues have reported that quinoid metabolites derived from catechol estrogens covalently modify multiple Keap 1 thiols as assessed by matrix-assisted laser desorption ionization time-of-flight mass spectrometry (MALDI-TOF MS) [23].

In the present study, we attempted to unravel the role of 4-OHE $\mathrm{H}_{2}$-induced $\mathrm{HO}-1$ overexpression in breast carcinogenesis and its underlying molecular mechanisms. We suggest that an electrophilic quinoid product derived from $4-\mathrm{OHE}_{2}$ metabolism activates Nrf2 through Keap1 thiol modification and subsequently induces HO-1 upregulation, thereby stimulating proliferation, migration and malignant transformation of human mammary epithelial cells.

\section{RESULTS}

\section{4-OHE ${ }_{2}$ induces both expression and activity of HO-1}

The expression of HO-1 was significantly elevated by $4-\mathrm{OHE}_{2}$, but not by the parent estrogen $\mathrm{E}_{2}$ in normal human breast epithelial MCF-10A cells and several breast cancer cells (Figure 1A). The induction of HO-1 expression was concentration-dependent (Figure 1B). 4- $\mathrm{OHE}_{2}$ also increased the $\mathrm{HO}$ activity as measured by the amounts of bilirubin formed (Figure 1C).

\section{Inhibition of HO-1 expression or activity impairs 4-OHE 2 -induced cell proliferation}

Previously, we reported that $4-\mathrm{OHE}_{2}$ induced neoplastic transformation of MCF-10A cells [9]. To investigate the putative role of $\mathrm{HO}-1$ in $4-\mathrm{OHE}_{2}$-induced mammary epithelial cell transformation, MCF-10A cells stably expressing empty retroviral silencing vector (mock), negative control vector (shNC), or HO-1 shRNA (shHO-1) were utilized. As shown in Figure 2A, silencing of $\mathrm{HO}-1$ gene resulted in pronounced suppression of $\mathrm{HO}-1$ protein expression in MCF-10A-shHO-1 cells. Notably, cells expressing HO-1 shRNA (MCF-10A-shHO-1) showed a significantly decreased proliferation after 24-h incubation in the absence or presence of $4-\mathrm{OHE}_{2}$ (Figure 2B). In another experiment, the stable knockdown of HO-1 gene $(H M O X 1)$ in MCF-10A-shHO-1 cells retarded cell migration, compared with that in MCF-10A-mock cells in the absence or presence of 4-OHE (Figure 2C). Moreover, pharmacologic inhibition of HO-1 with zinc protoporphyrin IX (ZnPP) resulted in suppression of $4-\mathrm{OHE}_{2}$-induced cell migration (Figure 2D). These results were further confirmed in a human breast cancer cell line (MDA-MB-231). When MDA-MB-231 cells were transfected with HO-1 plasmid (pc-DNA-HO-1), the cell migration was markedly enhanced which was reversed by ZnPP treatment (Figure 2E).

We next explored whether blockade of $\mathrm{HO}-1$ could impair the transforming capability of 4-OHE 2 . Treatment of MCF-10A-mock or MCF-10A-shNC cells with 4-OHE, twice a week for 3 weeks induced anchorage-independent cell growth, as evidenced by an increase in both the number and the size of colonies (Figure 2F). However, stable knockdown of HO-1 in MCF-10A-shHO-1 cells reduced colony formation more than $50 \%$ in the presence of 4-OHE ${ }_{2}$. Likewise, pharmacologic inhibition of HO-1 significantly reduced the 4-OHE - -induced anchorageindependent growth of MDA-MB-231 cells (Figure 2G). Taken together, these results suggest that HO-1 expression and activity contribute to the oncogenic potential of $4-\mathrm{OHE}_{2}$ in human mammary epithelial cells.

\section{4-OHE ${ }_{2}$ stimulates nuclear accumulation and ARE binding activity of Nrf2}

It was previously reported that $4-\mathrm{OHE}_{2}$ activated Nrf2 via the phosphatidylinositol-4,5-bisphosphate 3-kinase (PI3K) pathway [24]. As HO-1 induction is primarily regulated by Nrf2-ARE signaling, we first examined the effect of $4-\mathrm{OHE}_{2}$ on the expression of $\mathrm{Nrf} 2$. 4-OHE ${ }_{2}$ failed to alter $N r f 2$ mRNA (NFE2L2) expression (Figure 3A) but it enhanced nuclear translocation of Nrf2 more strongly than did the parent compound $\mathrm{E}_{2}$ (Figure $3 \mathrm{~B}$ ). $4-\mathrm{OHE}_{2}$-induced nuclear accumulation of $\mathrm{Nrf} 2$ was accompanied by transient reduction in its cytoplasmic levels followed by the increased expression of $\mathrm{HO}-1$ 
(Figure 3C). 4-OHE 2 -induced accumulation of $\mathrm{Nrf} 2$ in the nucleus of MCF-10A cells was also verified by immunocytochemical analysis (Figure 3D). Additionally, we examined the effect of $4-\mathrm{OHE}_{2}$ on $\mathrm{Nrf} 2$ transcriptional activity by use of the ARE luciferase reporter gene assay. The induction of ARE luciferase activity ( $>7$-fold) was observed after 6-h treatment of 4-OHE 2 (Figure $3 \mathrm{E}$ ).

\section{4-OHE -induced HO-1 expression is dependent on Nrf2 activation}

To determine whether 4-OHE -induced HO-1 up-regulation is mediated by $\mathrm{Nrf} 2$, we examined the level of HO-1 expression after Nrf2 knockdown. The 4-OHE induced promoter activity (Figure 4A) and expression (Figure 4B) of HO-1 were abolished by silencing $\mathrm{Nrf} 2$ gene with its specific siRNA. To further verify the role of Nrf2 in HO-1 induction, we utilized primary embryonic fibroblasts obtained from the Nrf2 wild-type (WT; $\mathrm{Nrf}^{+/+}$) and null $\left(\mathrm{Nrf}^{-/}\right)$mice. As shown in Figure $4 \mathrm{C}, 4-\mathrm{OHE}_{2}$ induced HO-1 expression was blunted in the fibroblasts derived from $\mathrm{Nrf2}^{-/-}$mice. We also employed the chromatin immunoprecipitation (ChIP) assay to more precisely assess Nrf2 interaction with the HO-1 gene promoter in the presence of $4-\mathrm{OHE}_{2}$. There was the strong binding of Nrf2 to only the distal E2 $(-9.0 \mathrm{~kb})$ region of the $\mathrm{HO}-1$ promoter harboring the ARE consensus sequence upon exposure to 4-OHE 2 (Figure 4D). Taken together, these results support that $4-\mathrm{OHE}_{2}$-induced $\mathrm{HO}-1$ expression is regulated mainly by $\mathrm{Nrf} 2$.

\section{Cysteine 288 of Keap1 is a putative target of 4-OHE 2 for HO-1 induction}

Upon its cysteine thiol modification, Keap1 liberates Nrf2 that translocates into the nucleus. We speculate that an electrophilic quinone species formed as a consequence of oxidation of 4-OHE 2 may directly bind and subsequently modify cysteine thiol(s) of Keap1, thereby facilitating the dissociation of Nrf2. The previous MALDI-TOF MS analysis has revealed that multiple reactive thiol groups of recombinant mouse Keap1 protein are subjected to modification by quinoid metabolites derived from catechol estrogens [23]. Here, we found that incubation of recombinant human Keap1 with 4-OHE 2 reduced the level of Keap1 modified by biotin-PEAC $\mathrm{C}_{5}$-maleimide (BPM),
A
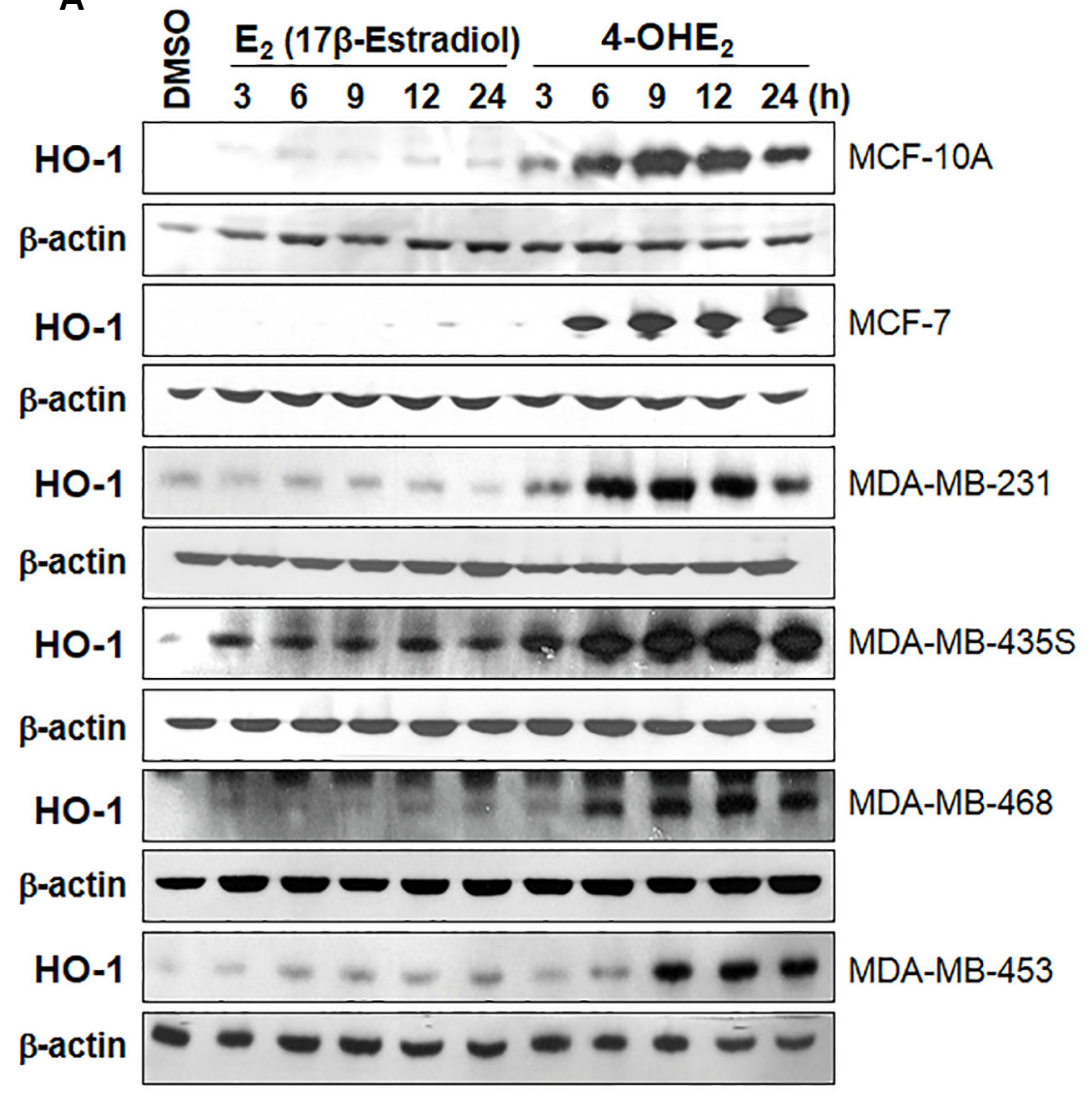

B
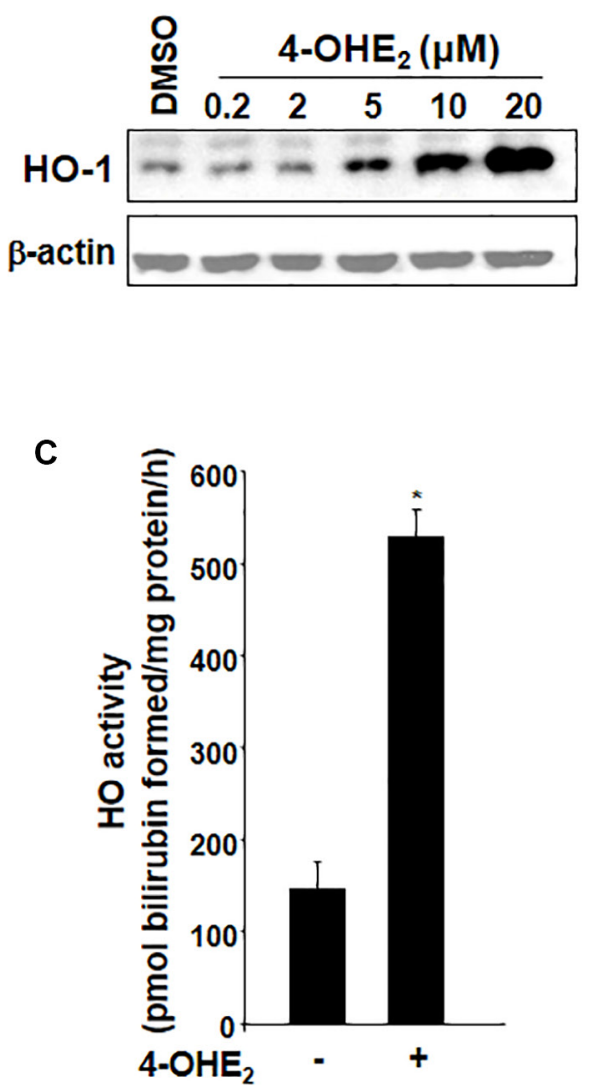

Figure 1: 4-OHE ${ }_{2}$ induces both expression and/or activity of HO-1 in human breast cells. (A) Each cell line was treated with $\mathrm{E}_{2}$ or $4-\mathrm{OHE}_{2}(20 \mu \mathrm{M})$ for the indicated time periods, and the expression of HO-1 was assessed by Western blot analysis. (B) MCF-10A cells were treated with various concentrations of $4-\mathrm{OHE}_{2}(0.2,2,5,10$, and $20 \mu \mathrm{M})$ for $6 \mathrm{~h}$ and the whole-cell lysates were subjected to Western blot analysis. (C) MCF-10A cells were treated with 4-OHE $2(20 \mu \mathrm{M})$ for $12 \mathrm{~h}$ and the $\mathrm{HO}$ activity was measured as described in Materials and Methods. $n=3 ;{ }^{*} P<0.001$. 
A

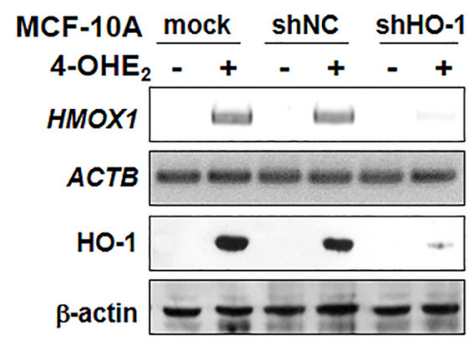

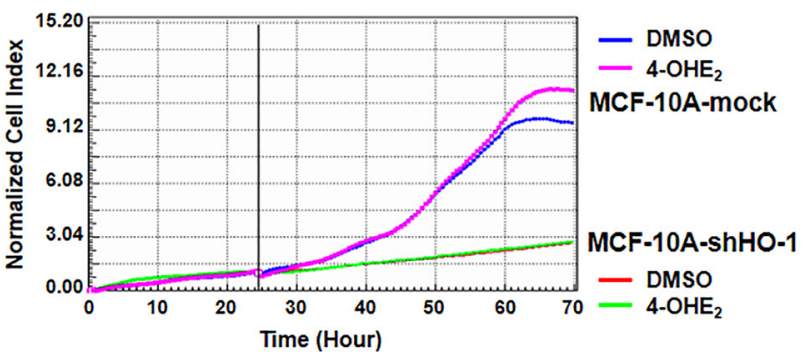

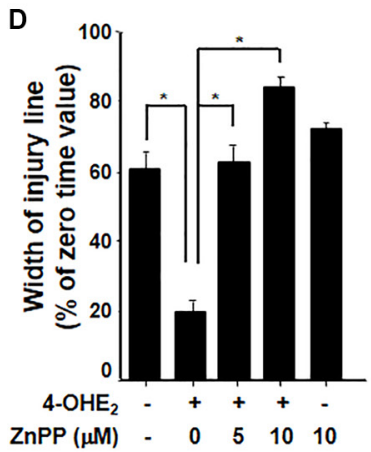

$\mathbf{E}$

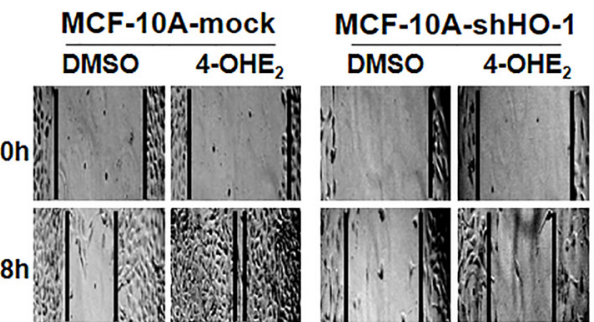

G

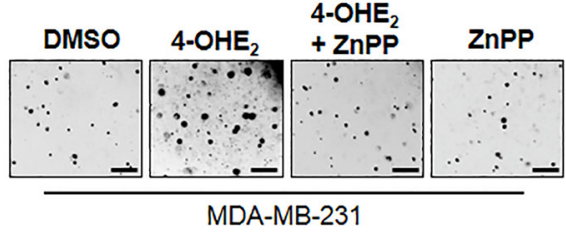

$\mathbf{F}$
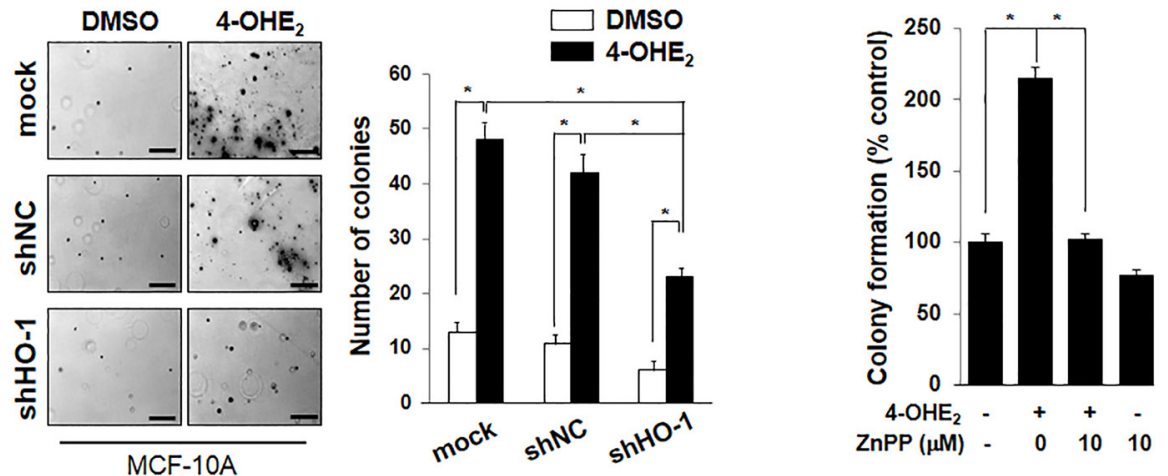

Figure 2: 4-OHE -induced HO-1 expression is associated with cell proliferation. (A) MCF-10A cells stably expressing mock, negative control (NC) shRNA or HO-1 shRNA were selected with $0.5 \mu \mathrm{g} / \mathrm{ml}$ puromycin. Cells were exposed to $4-\mathrm{OHE}_{2}(20 \mu \mathrm{M})$ for $6 \mathrm{~h}$ and analyzed for expression of HO-1 mRNA and protein by RT-PCR and Western blot analysis, respectively. HMOX1: HO-1 mRNA; $A C T B$ : $\beta$-actin mRNA. (B) MCF-10A-mock or MCF-10A-shHO-1 cells were treated with DMSO or $4-\mathrm{OHE}_{2}(5 \mu \mathrm{M})$ for $72 \mathrm{~h}$, and the cell proliferation was measured as described in Materials and Methods. (C-E), Cell migration was measured by using Culture-Inserts, and the wound closure was monitored by photography at indicated time points as described in Materials and Methods. (C) The representative images of migration assay are from MCF-10A-mock or MCF-10A-shHO-1 cells treated with DMSO or 4-OHE $2(20 \mu \mathrm{M})$ for $48 \mathrm{~h}$. (D) MCF-10A cells were treated with DMSO, 4-OHE $2(20 \mu \mathrm{M})$, or ZnPP (5 and $10 \mu \mathrm{M})$, separately or in combination for $24 \mathrm{~h}$. $n=3$; $* P<0.001$. (E) The representative images of migration assay are from MDA-MB-231 cells transfected with control vector (pcDNA) or HO-1 plasmid in the absence or presence of $\mathrm{ZnPP}(10 \mu \mathrm{M})$ for $12 \mathrm{~h}$. F-G. The anchorage-independent cell transformation assay was performed in MCF-10A or MDA-MB-231 cells as described in Material and Methods. Colonies were counted by using an inverted microscope (Nikon Diaphot 300). (F) MCF-10A-mock, MCF-10A-shNC, or MCF-10A-shHO-1 cells were treated with DMSO or 4-OHE $2(20 \mu \mathrm{M})$ once every 3 days for 3 weeks. Scale bars: $200 \mu \mathrm{m} . n=4$; $* P<0.001$. (G) MDA-MB-231 cells were treated with DMSO, 4-OHE $2(20 \mu \mathrm{M})$, or ZnPP $(10 \mu \mathrm{M})$, separately or in combination. Scale bars: $200 \mu \mathrm{m} . n=4 ; * P<0.001$. 
indicative of 4-OHE 2 binding to Keap1 (Figure 5A). $4-\mathrm{OHE}_{2}$ caused a decline in the band intensity for BPM bound to Keap1 in MCF-10A cells, corroborating the covalent modification of Keap 1 by this catechol estrogen (Figure 5B). Dithiothreitol (DTT), a well-known thiol reducing agent, also abrogated the interaction between BPM and Keap1. In another experiment, treatment of MCF-10A cells with DTT or a disulfide alkylating agent $N$-ethylmaleimide (NEM) repressed 4-OHE - -induced HO-1 expression in MCF-10A cells (Figure 5C).

Of the cysteine residues present in Keap1, Cys151, Cys273, and Cys288 are known to function as redox sensors [25-27]. To identify which cysteine residue of Keap1 is a primary target of $4-\mathrm{OHE}_{2}$, we constructed HA-tagged retroviral mutant vectors in which each of above cysteine residues was replaced by serine (C151S, C273S, and C288S). The stable cell lines expressing each of these mutant constructs as well as the WT cell line were treated with MG132, a cell-permeable proteasome inhibitor, $1 \mathrm{~h}$ before 4-OHE 2 treatment. Cell lysates were immunoprecipated with the antibody directed against the HA-Keap1, and the immunoprecipitated proteins were subjected to immunoblot analysis. The interaction between Keap1 and Nrf2 was not interrupted by 4-OHE in Keap1C273S or -C288S mutant cells (Figure 5D), and 4-OHE failed to induce HO-1 expression in these cells (Figure 5E). Moreover, induction of HO-1 expression by 4-OHE, was not prominent in cells which were co-transfected with expression vectors for Myc-Nrf2 and Keap1-Cys273S or Keap1-Cys288S (Figure 5F). To identify the specific cysteine residue(s) modified by $4-\mathrm{OHE}_{2}, \mathrm{MCF}-10 \mathrm{~A}$ cells overexpressing WT Keap1 were treated with this catechol estrogen. The proteins were digested with trypsin, and the resulting peptides were analyzed by nano-LC-ESI-MS/ MS. An increment of $287.15 \mathrm{Da}$ corresponding to the addition of a single molecule of $4-\mathrm{OHE}_{2}$-derived orthoquinone was observed in the peptide fragment containing Cys288 (Figure 5G). These results suggest that cysteine 288 of Keapl is likely to be a potential target of $4-\mathrm{OHE}_{2}$ for its activation of Nrf2-HO-1 signaling.

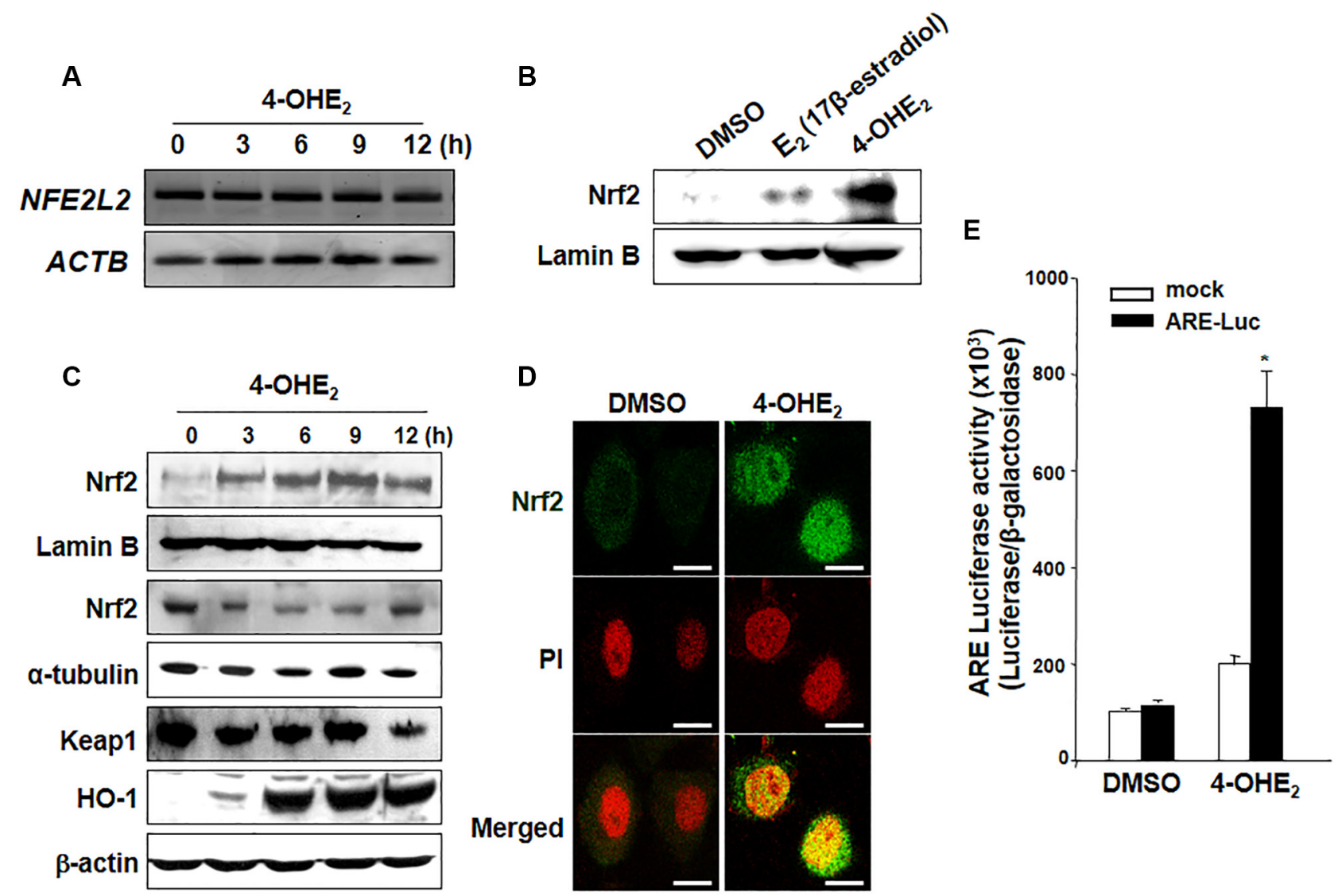

Figure 3: 4- $\mathrm{OHE}_{2}$ induces the nuclear translocation of Nrf2 and transcriptional activity of ARE. (A) MCF-10A cells treated with or without $4-\mathrm{OHE}_{2}(20 \mu \mathrm{M})$ were harvested at the indicated intervals, and total RNA was analyzed by RT-PCR to check the level of Nrf2 mRNA. NFE2L2: Nrf2 mRNA; ACTB: $\beta$-actin mRNA. (B) MCF-10A cells were treated with $\mathrm{E}_{2}$ or 4-OHE 2 (20 $\mu$ M, each) for $3 \mathrm{~h}$. The nuclear extracts were separated and subjected to Western blot analysis. (C) Nuclear, cytosol or whole extracts from MCF-10A cells were prepared at the indicated intervals after treatment with 4-OHE $2(20 \mu \mathrm{M})$, followed by Western blot analysis. (D) After the cells were treated with DMSO or 4-OHE $(20 \mu \mathrm{M})$ for $3 \mathrm{~h}$, immunofluorescence staining of Nrf2 was conducted as described in Materials and Methods. Scale bars: $10 \mu \mathrm{m}$. (E) MCF-10A cells were co-transfected with pCMV- $\beta$-galactosidase and either the luciferase reporter gene fusion construct (pTi-luciferase) or WT ARE and for $18 \mathrm{~h}$, followed by treatment with DMSO or 4-OHE ${ }_{2}$ for $6 \mathrm{~h}$. The cells were analyzed for the ARE transcriptional activity as described in Materials and Methods. $n=3 ; * P<0.001$. 
Inhibition of HO-1 activity attenuates the growth of 4-OHE -enhanced human breast cancer cell xenograft

Because HO-1 appears to mediate the carcinogenic activity of 4-OHE 2 , we examined whether suppression of HO-1 activity could affect the 4-OHE - -induced growth of MDA-MB-231 human mammary cancer cells transplanted to athymic mice. As shown in Figure 6A, tumor growth was increased in mice receiving $4-\mathrm{OHE}_{2}$, but significantly suppressed by co-treatment with ZnPP. Thus, the average volume (Figure 6B) and mass (Figure 6C) of tumors in 4- $\mathrm{OHE}_{2}$-treated mice were almost completely reduced by pharmacologic inhibition of HO-1. It is noticeable that the enhanced growth of MDA-MB-231 cell xenografts by 4- $\mathrm{OHE}_{2}$ treatment was associated with a marked increase in the expression levels of CA15-3 (Figure 6D), which is a typical diagnostic marker of breast tumor. Pharmacologic
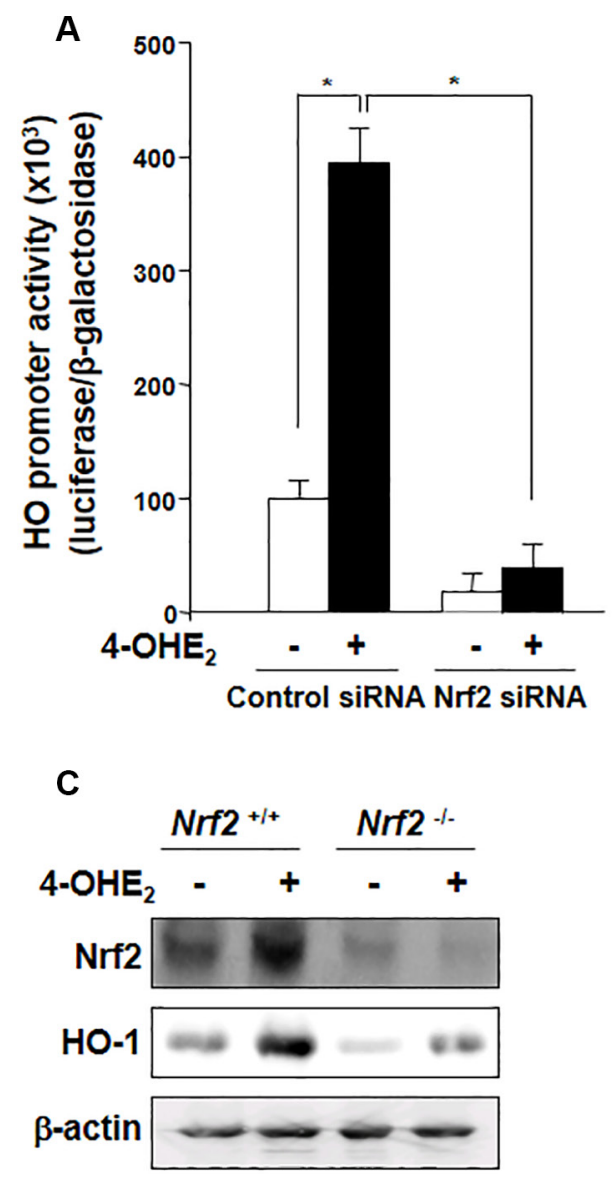

inhibition of HO-1 with ZnPP also reduced the CA15-3 expression and suppressed the tumor cell proliferation as evidenced by decreased expression of proliferating cell nuclear antigen (PCNA). Inappropriate up-regulation of cyclooxygenase-2 (COX-2) correlates with the increased angiogenesis and metastatic potential in breast cancer cells $[28,29] .4-\mathrm{OHE}_{2}$-induced $\mathrm{COX}-2$ overexpression in MDA-MB-231 human breast tumor xenografts was also inhibited by ZnPP treatment (Figure 6D). Taken together, these data suggest that HO-1 plays a critical role in $4-\mathrm{OHE}_{2}$-mediated breast cancer progression.

\section{DISCUSSION}

It has been reported that HO-1 is overexpressed in several human tumors [30-32]. In this study, we found that $4-\mathrm{OHE}_{2}$, one of the putative oncogenic metabolites of $\mathrm{E}_{2}$, upregulated the expression of $\mathrm{HO}-1$ in human
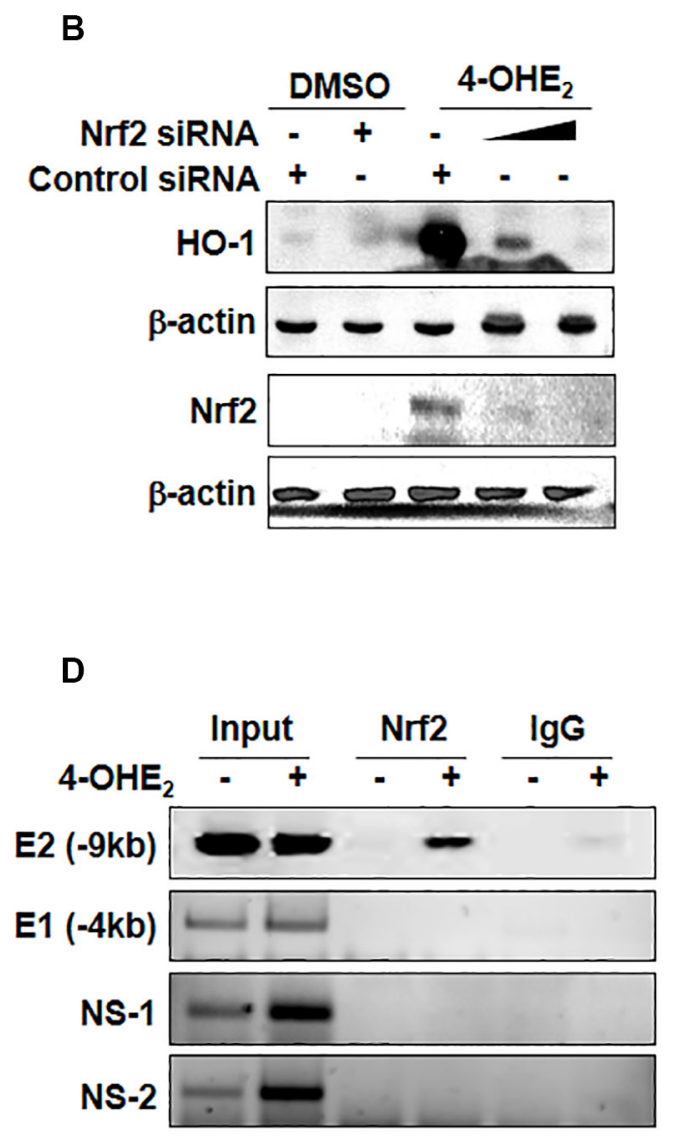

Figure 4: 4-OHE -induced HO-1 expression is mediated through Nrf2 activation. (A) MCF-10A cells were co-transfected with luciferase reporter plasmid construct harboring the HO-1 binding site (pGL2-HO-1) and pCMV- $\beta$-galactosidase with control siRNA or

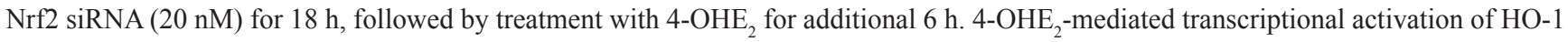
was measured by the luciferase reporter assay as described in Materials and Methods. $n=3 ; * P<0.001$. (B) Cells were transfected with control siRNA or Nrf2 siRNA $(20 \mathrm{nM})$ for $18 \mathrm{~h}$ and exposed to 4-OHE $2(20 \mu \mathrm{M})$ for another $6 \mathrm{~h}$. The cell lysates were subjected to Western blot analysis. (C) The effect of Nrf2 on the expression of HO-1 was assessed by using embryonic fibroblasts from $\mathrm{Nrf} 2 \mathrm{WT}\left(\mathrm{Nrf} 2^{+/+}\right)$and $\mathrm{Nrf2}$-null $\left(\mathrm{Nrf2}^{-/}\right)$mice. The cells were exposed to 4-OHE $2(20 \mu \mathrm{M})$ for $6 \mathrm{~h}$ and subjected to Western blot analysis. (D) MCF-10A cells were treated with DMSO or 4-OHE $(20 \mu \mathrm{M})$ for $6 \mathrm{~h}$ and harvested for the ChIP assay. Chromatin immunoprecipitated DNA was analyzed by PCR with primers for distal E2 ( $-9.0 \mathrm{~kb}$ region) ARE, E1 (-4.0 kb region) ARE, and two non-specific regions (NS-1 and NS-2) of the HO-1 promoter. 


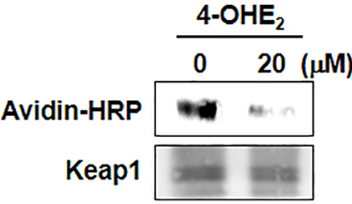

B

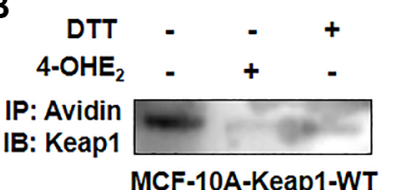

MCF-10A-Keap1-WT

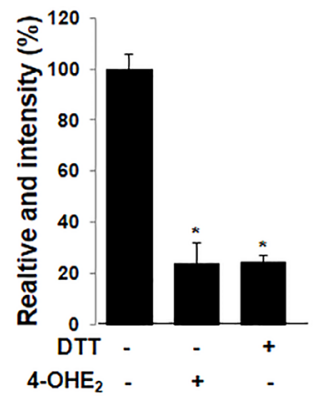

D

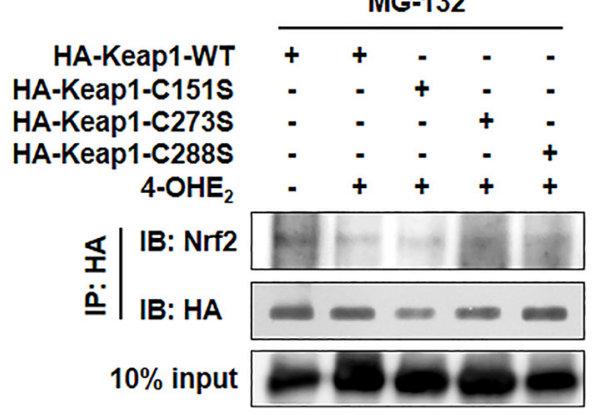

C
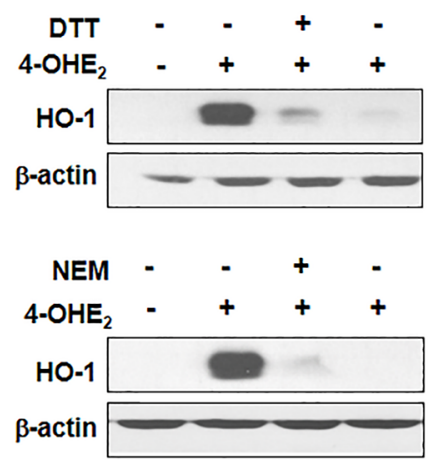

E

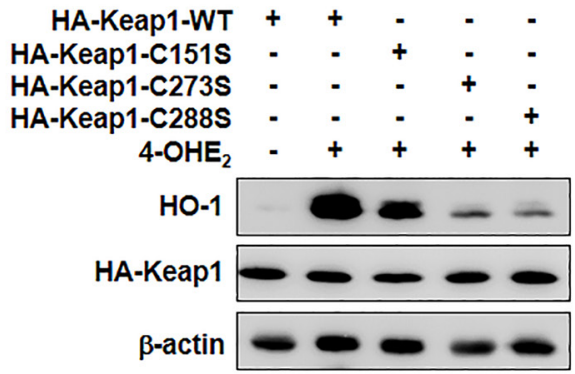

$\mathbf{F}$

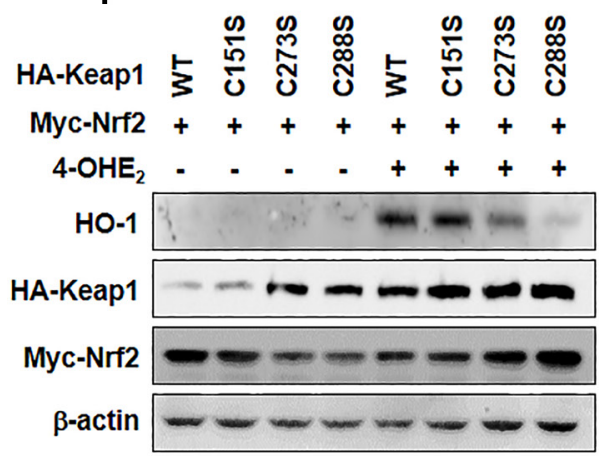

G

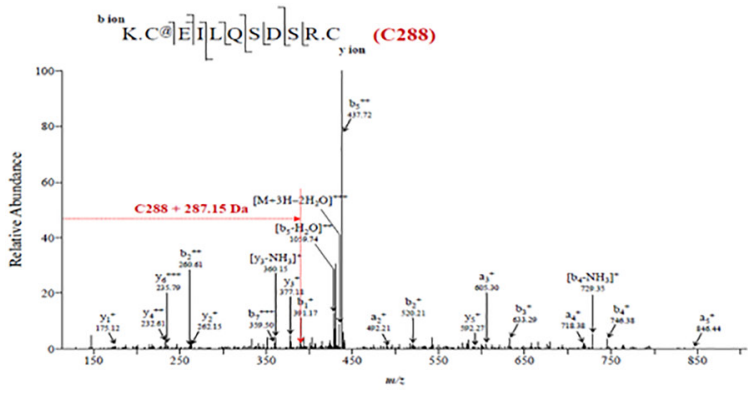

Figure 5: The thiol modification of Keap1 is responsible for 4-OHE ${ }_{2}$-induced $\mathrm{Nrf2}$ activation and $\mathrm{HO}-1$ expression. (A) Recombinant human Keap1 protein was reacted with DMSO or 4-OHE $(20 \mu \mathrm{M})$ for $30 \mathrm{~min}$, and then incubated with BPM $(50 \mu \mathrm{M})$ for additional $30 \mathrm{~min}$. The resulting protein was subjected to Western blot analysis with an anti-biotin antibody. (B) MCF-10A-Keap1 WT cells were incubated with DMSO, 4-OHE $(20 \mu \mathrm{M})$, or DTT $(100 \mu \mathrm{M})$ for $1 \mathrm{~h}$ and then lysed with RIPA buffer. The cell lysates were subjected to the BPM-labeling assay as described in Materials and Methods. $n=3 ; * P<0.001$. (C) MCF-10A cells were pre-treated with DTT $(100 \mu \mathrm{M})$ or NEM $(25 \mu \mathrm{M})$ for $1 \mathrm{~h}$, followed by $6 \mathrm{~h}$ incubation with $20 \mu \mathrm{M}$ 4-OHE . Whole cell lysates were subjected to Western blot analysis. (D) MCF-10A cells stably expressing HA-Keap1-WT, HA-Keap1-C151S, HA-Keap1-C273S, or HA-Keap1-C288S were pre-treated with MG-132 $(10 \mu \mathrm{M})$ for $1 \mathrm{~h}$ and then treated with DMSO or 4-OHE $(20 \mu \mathrm{M})$. The proteins were lysed with RIPA buffer and immunoprecipitated with anti-HA antibody. The immunoprecipitated proteins were subjected to Western blot analysis with an anti-Nrf2 or anti-HA antibody. (E) MCF-10A-Keap1 WT or each mutant cells were incubated with DMSO or 4-OHE $2(20 \mu \mathrm{M})$ for $6 \mathrm{~h}$, and the whole cell lysates were assessed by Western blot analysis. (F) MCF-10A cells were co-transfected with an expression vector for Myc-Nrf2 and an expression vector for either WT Keap1 or mutant Keap1 for $18 \mathrm{~h}$. The transfected cells were treated with DMSO or 4-OHE $2(20 \mu \mathrm{M})$ for additional $6 \mathrm{~h}$, and then cell lysates were subjected to Western blot analysis. (G) MCF-10A cells stably expressing WT Keap1 were incubated with DMSO or 4-OHE $(20 \mu \mathrm{M})$ for $1 \mathrm{~h}$, and the proteins were subjected to in-gel digestion. Digested peptide fragments were subjected to mass spectrometry as described in Materials and Methods. 
breast epithelial cells and multiple breast cancer cells. HO-1 expression was induced by $4-\mathrm{OHE}_{2}$, not by the parent compound $\mathrm{E}_{2}$, through activation of $\mathrm{Nrf} 2$ which might result from the direct binding of $4-\mathrm{OHE}_{2}$-derived electrophilic quinone species to Cys288 of Keap1. This $4-\mathrm{OHE}_{2}$-mediated thiol modification of Keap1 activates Nrf2-HO-1 signaling, which contributes to enhanced proliferation and transformation of mammary epithelial cells, and stimulation of breast cancer cell growth.

The oncogene-induced Nrf2 transcription has been proposed to promote tumorigenesis [33], and the elevated expression/activity of HO-1, one of the major Nrf2 target proteins, can affect tumor cell proliferation, invasion, metastasis, and chemoresistance [13, 15, 34, 35]. Our previous study has demonstrated that 15-deoxy$\Delta^{12,14}$-prostaglandin $\mathrm{J}_{2}$, formed during COX-2-catalyzed arachidonic acid metabolism, upregulates HO-1 expression and subsequently provokes ROS formation, which may account for increased invasiveness and metastatic potential of human breast cancer cells [36]. HO-1 knockdown led to pronounced inhibition of the pancreatic cancer cell growth and made tumor cells significantly more sensitive to radiotherapy and chemotherapy [31]. Cobalt protoporphyrin (CoPP), an inducer of HO-1 expression and activity, enhanced the vGPCR-induced tumor growth while a HO-1 inhibitor SnPP treatment caused a remarkable reduction [37]. Moreover, ZnPP and its watersoluble pegylated form (PEG-ZnPP) have been found to act as anti-neoplastic agents when given to mice bearing tumors [17, 38].

Some cysteine residues present in Keap1 that functions as redox sensors are recognized as potential targets of thiol-reactive chemical species capable of inducing Nrf2 activation [20, 25, 26, 39]. It has been reported that mutation of Cys151, Cys273, or Cys 288 negates Keap1 functional activity [25, 26, 39-42]. Covalent modification of Cys 273 or Cys 288 induces conformational changes in the intervening region (IVR)
A
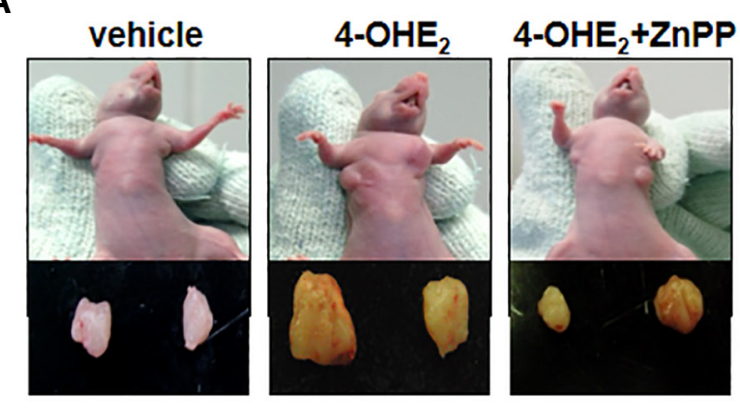

C

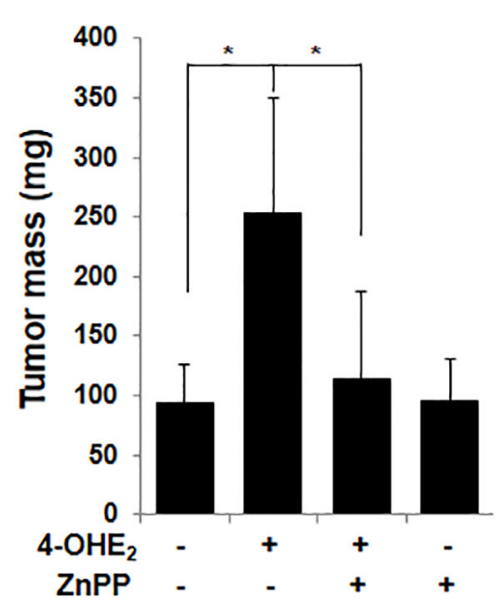

D

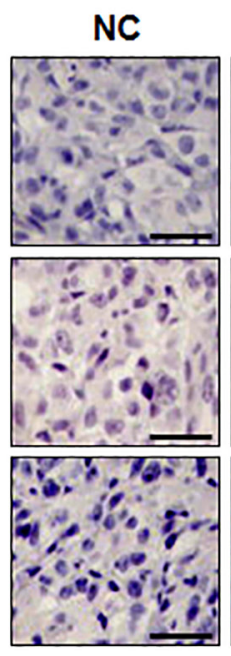

B
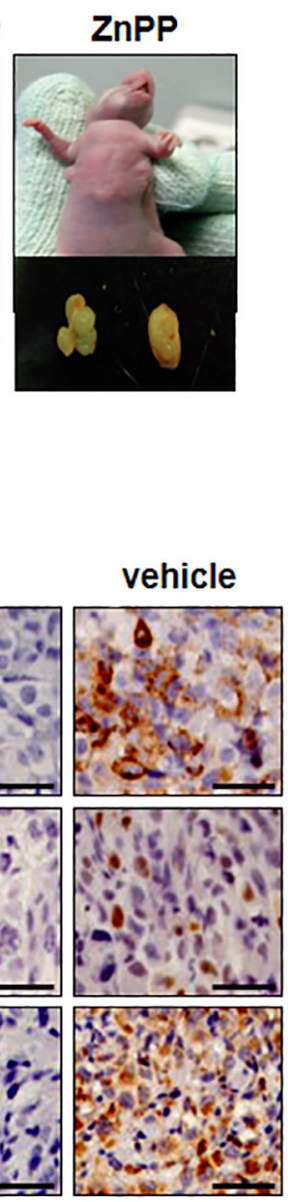
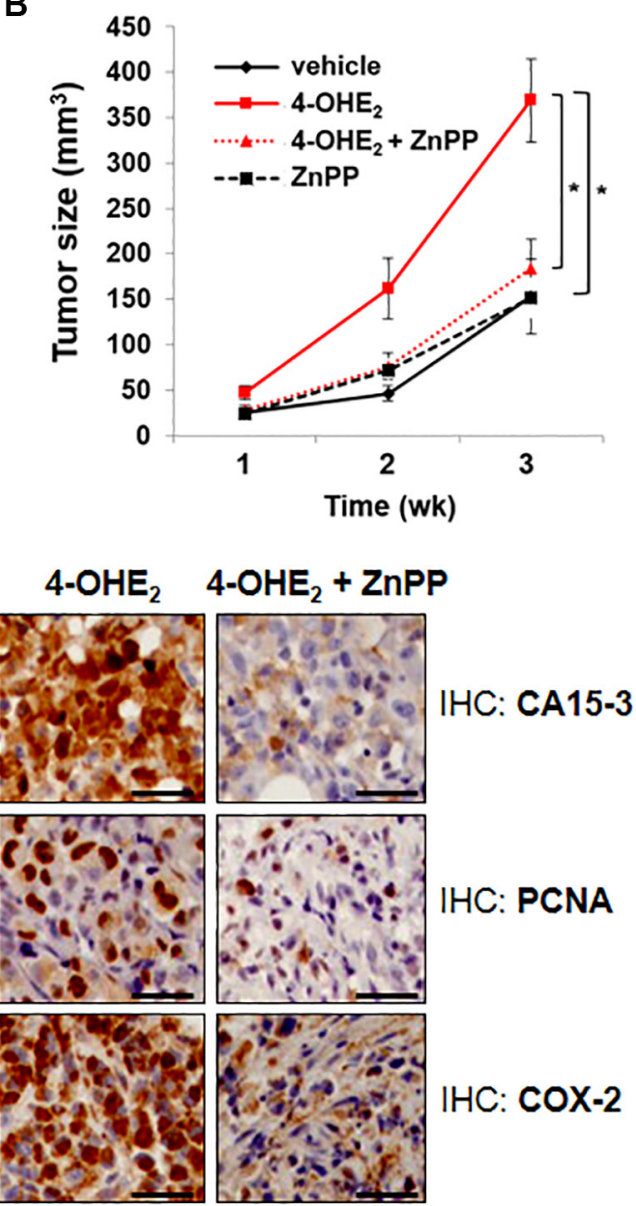

Figure 6: Inhibition of HO-1 activity by ZnPP impairs 4-OHE images of human mammary tumor (MDA-MB-231) xenografts in mice treated with vehicle, 4-OHE 2 , 4-OHE 2 plus $\mathrm{ZnPP}$, or $\mathrm{ZnPP}$ for 3 weeks ( $n=12$ /group). (B) The effect of each treatment on the tumor volume of MDA-MB-231 cell xenograft was measured with digital calipers and calculated by the formula $0.52 \times$ length $\times$ width $^{2}$. Vehicle vs $4-\mathrm{OHE}_{2}$ or $4-\mathrm{OHE}_{2}$ vs $4-\mathrm{OHE}{ }_{2}+\mathrm{ZnPP} ;{ }^{*} P<0.001(\mathrm{Two}-$ sided $t$-test). (C) The effects of each treatment on the tumor mass were measured. ${ }^{*} P<0.001$ (Two-sided $t$-test). (D) The effect of each treatment on the expression of the indicated genes was examined by immunohistochemical analysis as described in Materials and Methods (Magnification, $\times 400$ ). NC: negative control, Scale bars: $50 \mu \mathrm{m}$. 
of Keap1 and affects the interaction between IVR of Keap1 and the Neh2 domain of Nrf2 while modification of Cys151 does not impair recognition of Nrf2, but rather causes dysfunction of the E3 ligase [27]. Notably, our mass spectral analysis indicates that $4-\mathrm{OHE}_{2}$ directly interacts with the Cys288 residue of an endogenous form of Keap1 expressed in human breast epithelial cells, suggesting that this particular cysteine could be a bona fide target of this catechol estrogen in its activation of $\mathrm{Nrf} 2$ and upregulation of HO-1 expression.

Several studies have reported that mitogen-activated protein kinases (MAPKs) and Akt are involved in $\mathrm{Nrf} 2$ activation [43-45]. 4- $\mathrm{OHE}_{2}$ was shown to activate the ARE by a PI3K/ Akt-dependent mechanism [24]. ROS overproduced by $4-\mathrm{OHE}_{2}$ was found to cause the increased phosphorylation of extracellular signal-regulated kinase (ERK) and Akt [9]. Results from our preliminary study demonstrate the ROS-mediated activation of PI3K-Akt signaling as an alternative mechanism underlying 4-OHE $\mathrm{H}_{2}$-induced Nrf2 activation and $\mathrm{HO}-1$ upregulation (Supplementary Figure 1).

In conclusion, our data show that $4-\mathrm{OHE}_{2}$ induces upregulation of $\mathrm{HO}-1$ through $\mathrm{Nrf} 2$ activation, and genetic or chemical inhibition of this enzyme abrogates $4-\mathrm{OHE}_{2}-$ induced mammary epithelial cell transformation and growth of tumor xenografts. These results provide a novel molecular mechanism of $4-\mathrm{OHE}_{2}$-induced progression of mammary carcinogenesis. Considering that HO-1 is overexpressed in several cancers including breast cancer, the targeted inhibition of intratumoral HO-1 activity and/ or expression may be a potential clinical interest in future anticancer therapy.

\section{MATERIALS AND METHODS}

\section{Reagents}

4- $\mathrm{OHE}_{2}$ and $\mathrm{E}_{2}$ were purchased from Sigma Chemical Co. Rabbit polyclonal HO-1 antibody was purchased from Stressgen. The primary antibody of Nrf2, Keap1, and PCNA were purchased from Santa Cruz Biotechnology. Anti-CA 15-3 was obtained from Fitzgerald. The primary antibody for COX-2 was purchased from Neomarker. ZnPP was supplied from Alexis Corporation. Matrigel basement membrane matrix was purchased from BD Bioscience. HO-1 short interfering RNA (siRNA) was purchased from Invitrogen. HO-1 plasmid was kindly provided by Prof. Jozef Dulak (Jagiellonian University, Krakow, Poland). $N$-Acetyl-L-cysteine (NAC), trolox, DTT, NEM and an antibody against actin were also purchased from Sigma Chemical Co. The primary antibodies of lamin $\mathrm{B}$ and $\alpha$-tubulin and anti-rabbit horseradish peroxidaseconjugated secondary antibody were products of Zymed Laboratories Inc. The inhibitors of ERK (U0126) and PI3K (LY294002) were purchased from TOCRIS. BPM was obtained from DOJINDO. Human recombinant Keap1 protein was purchased from Abnova. Avidin agarose was a product of Pierce. The ECL chemiluminescent detection kit was obtained from Amersham Pharmacia Biotech. The human specific Nrf2 siRNA (sense 5'-AAGAGUAUGAGCUGGAAAAACTT-3'; antisense 5'-GUUUUUCCAGCUCAUAC UCUUTT-3') and Stealth $^{\mathrm{TM}}$ RNAi negative control duplexes were provided by Invitrogen. The luciferase assay kit was purchased from Promega.

\section{Cell culture}

MCF-10A, MCF-7, MDA-MB-231, MDAMB-435S, MDA-MB-453, and MDA-MB-468 cells were originally obtained from American Type Culture Collection and cultured according to the manufacturer's instruction. All cells were passaged directly from the original low-passage stocks and were used before passage 30. The cells were examined within the last three months for correct morphology under a microscope and tested to detect mycoplasma contamination using an e-Myco ${ }^{\mathrm{TM}}$ plus mycoplasma polymerase chain reaction (PCR) detection kit (iNtRON Biotechnology). Cells are maintained at $37^{\circ} \mathrm{C}$ in a humidified atmosphere composed of $5 \% \mathrm{CO}_{2} /$ $95 \%$ air.

\section{Reverse transcription PCR (RT-PCR)}

Total RNA was isolated from cells using TRIzol ${ }^{\circledR}$ (Invitrogen). One microgram of total RNA was used for the complementary DNA synthesis using random primers. RT-PCR was performed following standard procedures. PCR conditions for NFE2L2 (Nrf2) and $A C T B$ ( $\beta$-actin) were as follows: 26 cycles of $94^{\circ} \mathrm{C}$ for $1 \mathrm{~min} ; 60^{\circ} \mathrm{C}$ for $1 \mathrm{~min}$ and $72^{\circ} \mathrm{C}$ for $1 \mathrm{~min}$. The primer pairs and the size of the expected products were as follows: NFE2L2, 5'-CGGTATGCAACAGGACATTG-3' and 5'-ACTGGTTGGGGTCTTCTGTG-3', 263 bp and ACTB, 5'-CTCTTCCAGCCTTCCTTCCT-3' and 5'- AGC ACTGTGTTGGCGTACAG-3', 211 base pairs. Amplification products were resolved by $1.0 \%$ agarose gel electrophoresis, stained with ethidium bromide and photographed under ultraviolet light.

\section{Western blot analysis}

Standard SDS-PAGE and Western blotting procedures were used to analyze the expression of various proteins. Cell lysates were prepared using SDS lysis buffer (50 mM Tris-HCl, pH 6.8, 2\% SDS, 10\% glycerol, and $0.02 \%$ bromophenol blue) containing protease inhibitors and phosphatase. All proteins were visualized using a horseradish peroxidase-conjugated secondary antibody and Amersham ECL ${ }^{\mathrm{TM}}$ Western Blotting Detection Reagents (GE Healthcare Life Sciences). 


\section{ChIP assay}

DNA and proteins of the cells were cross-linked with $37 \%$ formaldehyde for $10 \mathrm{~min}$ at room temperature. The cells were washed with ice-cold phosphate-buffered saline (PBS) containing protease inhibitor cocktail tablets (Roche Molecular Biochemicals), scraped in PBS, and centrifuged at 2,000 $\mathrm{g}$ for $5 \mathrm{~min}$. Pellets were suspended in SDS lysis buffer [1\% SDS, $10 \mathrm{mM}$ EDTA, $50 \mathrm{mM}$ Tris (pH 8.1)] with protease inhibitor cocktail tablets. Lysates were sonicated to 200- to 1000-bp in length on ice and centrifuged at 13,000 $\times g$ for $10 \mathrm{~min}$. ChIP dilution buffer containing protease inhibitor cocktail tablets was mixed with the supernatant chromatin. Each sample was immunoprecipitated with $5 \mu \mathrm{g}$ of specific Nrf2 antibody or normal mouse IgG overnight at $4{ }^{\circ} \mathrm{C}$ rotation. Immune complexes were precipitated with protein $\mathrm{G}$ agarose beads (Santa Cruz Biotechnology) for $4 \mathrm{~h}$ at $4^{\circ} \mathrm{C}$ with rotation. The pellets were washed once with low salt immune complex wash buffer ([0.1\% SDS, $1 \%$ Triton X-100, 2 mM EDTA, and $20 \mathrm{mM}$ Tris- $\mathrm{HCl}$ (pH 8.1), and $150 \mathrm{mM} \mathrm{NaCl}$, once with high salt immune complex wash buffer [0.1\% SDS, $1 \%$ Triton X-100, 2 mM EDTA, $20 \mathrm{mM}$ Tris- $\mathrm{HCl}(\mathrm{pH} 8.1)$, and $500 \mathrm{mM} \mathrm{NaCl}]$, once with $\mathrm{LiCl}$ immune complex wash buffer $[0.25 \mathrm{M} \mathrm{LiCl}, 0.5 \%$ NP-40, 1\% deoxycholic acid, $1 \mathrm{mM}$ EDTA, and $10 \mathrm{mM}$ Tris- $\mathrm{HCl}(\mathrm{pH} 8.1)]$, and twice with TE buffer $[10 \mathrm{mM}$ Tris- $\mathrm{HCl}(\mathrm{pH} 8.1)$, and $1 \mathrm{mM}$ EDTA]. DNA-protein complexes were eluted from protein $\mathrm{G}$ agarose beads with an elution buffer $\left[0.1 \mathrm{M} \mathrm{NaHCO}_{3}\right.$ and $1 \%$ SDS]. Crosslinking was reversed at $65^{\circ} \mathrm{C}$ overnight, and DNA was extracted using the AccuPrep Genomic DNA Extraction Kit (Bioneer) according to the manufacturer's protocol. PCR was performed against the $\mathrm{E} 2 \mathrm{ARE}$ of the $\mathrm{HO}-1$ promoter (primers; 5'-CCCTGCTGAGTAATCCTTTCCCGA-3' and 5'-ATGTCCCGACTCCAGACTCCA-3'), and the PCR condition was as follows: 40 cycles of $94^{\circ} \mathrm{C}$ for $1 \mathrm{~min}, 60^{\circ} \mathrm{C}$ for $1 \mathrm{~min}$, and $72^{\circ} \mathrm{C}$ for $1 \mathrm{~min}$. PCR was also performed against the E1 ARE (primers; 5'-CTGCCCAAACC ACTTCTGTT-3' and 5'-ATAAGAAGGCCTCGGTGG AT-3') and two non-specific (NS) ARE regions of the HO-1 promoter (NS-1 primers; 5'-GCTATGTGGGAGGTT GAGGA-3' and 5'-CCATGGTCAGCAGTTTGCTA3', NS-2 primers; 5'-TTGCCTTGTCACGTTTTCAC-3' and 5'-TGCCTTGGTGTCTCAGAGTG-3'). The PCR condition was as follows: 40 cycles of $94^{\circ} \mathrm{C}$ for $1 \mathrm{~min}$, $50^{\circ} \mathrm{C}$ for $1 \mathrm{~min}$, and $72^{\circ} \mathrm{C}$ for $1 \mathrm{~min}$.

\section{Site-directed mutagenesis}

Site-directed mutagenesis was performed by PCR using DNA primers obtained from Bioneer with single-, double- or triple-based mismatches, resulting in the desired amino acid substitution according to the manufacturer's instruction (Intron Biotechnology). The correct sequence of all constructs was confirmed by sequencing analysis (Cosmo Genetech).

\section{Measurement of HO-1 activity}

$\mathrm{HO}$ activity was measured by determining the rate of bilirubin production according to the previously described method [46, 47]. Harvested cells were washed twice with cold PBS, scraped in the presence of cold homogenization buffer containing $30 \mathrm{mM}$ Tris- $\mathrm{HCl}(\mathrm{pH} 7.5), 0.25 \mathrm{M}$ sucrose, $0.15 \mathrm{M} \mathrm{NaCl}$, and a mixture of protease inhibitors, homogenized, and centrifuged at $10,000 \times g$ for $15 \mathrm{~min}$ at $4{ }^{\circ} \mathrm{C}$. The supernatant was collected and centrifuged again at $100,000 \times g$ for $1 \mathrm{~h}$ at $4^{\circ} \mathrm{C}$. The obtained microsomal pellet was resuspended in $100 \mathrm{mM}$ potassium phosphate buffer ( $\mathrm{pH}$ 7.4) containing $2 \mathrm{mM} \mathrm{MgCl}_{2}$, $10 \mu \mathrm{g} / \mathrm{ml}$ leupeptin, $10 \mu \mathrm{g} / \mathrm{ml}$ trypsin inhibitor, $2 \mu \mathrm{g} / \mathrm{ml}$ aprotinin, and $1 \mathrm{mM}$ phenylmethylsulfonyl fluoride. This microsomal fraction was added to the reaction mixture containing $0.8 \mathrm{mM}$ NADPH, $2 \mathrm{mM}$ glucose 6-phosphate, $0.2 \mathrm{U}$ of glucose-6-phosphate dehydrogenase, $20 \mu \mathrm{M}$

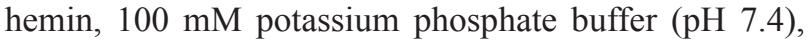
and $2 \mathrm{mg}$ of rat liver cytosol as a source of biliverdin reductase. Mixtures were incubated at $37^{\circ} \mathrm{C}$ for $1 \mathrm{~h}$ in the dark, and the samples were left in an ice bath for at least 2 min to terminate the reaction. Bilirubin formed was determined by calculation of the differences in absorbance between 464 and $530 \mathrm{~nm}$.

\section{Generation of cells expressing HO-1 shRNA}

The sequences of HO-1 shRNA and negative control shRNA (shNC) obtained from OriGene Technologies were as follows: HO-1 shRNA, TCCTTAC ACTCAGCTTTCTGGTGGCGACA and shNC, TGACCA CCCTGACCTACGGCGTGCAGTGC. Each sequence was cloned into a retroviral silencing (pRS) vector. Cells stably expressing original pRS vector (mock), shNC or HO-1 shRNA were selected with $0.5 \mu \mathrm{g} / \mathrm{ml}$ puromycin (Invivogen).

\section{Cell proliferation assay}

MCF-10A-mock or MCF-10A-shHO-1 cells were plated at a density of $2 \times 10^{3}$ cells/well in the E-Plate 96 (Roche Diagnostics Corporation) for $24 \mathrm{~h}$. Each of the 96 wells on the E-Plate 96 contains integral sensor electrode arrays so that cells inside each well can be monitored. The cells were incubated for another $72 \mathrm{~h}$ in the absence or presence of 4-OHE ${ }_{2}$ in the Real-Time Cell Analyzer (Roche Diagnostics Corporation).

\section{Wound migration assay}

The Culture-Inserts (Ibidi) were transferred to 6-well plates, and cells $\left(7 \times 10^{4} /\right.$ well $)$ were seeded in CultureInserts. After 24-h incubation, the Inserts were removed and cells were treated with the medium containing each agent. Phase contrast images of the closed gap were 
captured at the indicated time of incubation using an inverted microscope (magnification, $\times 10$ ).

\section{Anchorage-independent growth assay}

To prepare hard agar layer, 3.3\% agarose dissolved in PBS was boiled, and the agarose solution was added to $60 \mathrm{~mm}$-dishes and kept in the $37^{\circ} \mathrm{C}$ incubator to solidify. To prepare the soft agar layer, cells were suspended in the $0.33 \%$ agarose solution, and the mixture was inoculated on top of the hard agar layer. After 4-h incubation, fresh media was added to the top of the soft agar layer, and the cells were exposed to $4-\mathrm{OHE}_{2}$ or vehicle, once in 3 days. After incubation for 3 to 4 weeks, anchorage-independent growth (spherical formation containing $>10$ cells) was scored under a light microscope. The experiments were replicated 4 times, and a representative set of data was photographed.

\section{Luciferase reporter assay}

The cells were seeded in a 6-well plates and grown to $60-70 \%$ confluence. MCF-10A cells were co-transfected with $\mathrm{pCMV}-\beta$-galactosidase and either the luciferase reporter gene fusion construct ( $\mathrm{pTi}$ luciferase) or WT ARE. Cells were also co-transfected with a luciferase reporter plasmid construct harboring the HO-1 binding site (pGL2-HO-1) and pCMV- $\beta$ galactosidase with control siRNA or Nrf2 siRNA. After 18-h transfection, the medium was changed, and cells were treated with $4-\mathrm{OHE}_{2}$ for additional $6 \mathrm{~h}$. The cells were then washed with PBS and lysed in reporter lysis buffer (Promega). The lysed cell extract was mixed with the luciferase assay reagent, and the luciferase activity was determined using a luminometer (AntoLumat LB 953). The $\beta$-galactosidase assay (Promega) was done to normalize the luciferase activity.

\section{Preparation and maintenance of mouse embryonic fibroblasts}

The Nrf2 wild type $\left(\mathrm{Nrf}^{+/+}\right)$and Nrf2-null $\left(\mathrm{Nrf2}^{-/}\right)$mice were provided by Dr. Jeffery Johnson (University of Wisconsin, Madison, USA). After inhouse breeding, the $\mathrm{Nrf2}^{-}, \mathrm{Nrf2}^{+-}$and WT mice were maintained in the animal quarters in accordance with Seoul National University guidelines for animal care and were housed in a 12-h light/12-h dark cycle. Male and female $\mathrm{Nrf2}^{+-}$mice were mated and embryos were obtained at the day 13.5 after pairing under aseptic conditions. The heads of the embryos were used to confirm the $N r f 2$ genotype by RT-PCR, and the embryo bodies were minced into small pieces and cultured in high glucose DMEM supplemented with $10 \%$ FBS and kept at $37^{\circ} \mathrm{C}$ with $5 \% \mathrm{CO}_{2}$.

\section{Immunofluorescence staining}

The cells were rinsed with PBS and fixed with $4 \%$ formaldehyde for $30 \mathrm{~min}$ at room temperature. After washing with PBS, the fixed cells were incubated in PBS containing $10 \%$ BSA and $0.5 \%$ Tween-20 for $2 \mathrm{~h}$ at room temperature. After incubation with an Nrf2 antibody (1:100 dilution) overnight at $4{ }^{\circ} \mathrm{C}$, the cells were washed with PBS and labeled with diluted (1:1000) FITC-conjugated goat anti-rabbit IgG (Zymed Laboratories) for additional $1 \mathrm{~h}$ at room temperature. After washing with PBS, cells were stained with propidium iodide (PI), visualized under a confocal microscope and photographed (Leica Microsystems Heidelberg $\mathrm{GmbH})$.

\section{Generation of stable cells expressing Keap1 constructs}

pBabe parental vector (pBabe-puro-HA-VHL) was purchased from Addgene and Keap1-C151S, -C273S, and $-\mathrm{C} 288 \mathrm{~S}$ cDNAs were obtained using Muta-Direct ${ }^{\mathrm{TM}}$ (iNtRON Biotechnology). PCR-amplified WT Keap1, Keap1-C151S, -C273S, or-C288S cDNA was subcloned into the parental vectors. Recombinant retroviruses were produced as described previously [48]. Briefly, HEK293T cells were transiently transfected with each retroviral construct and packaging vectors (gag-pol and VSVG). After 24-h transfection, the media were changed, and the virus containing media was collected at $48 \mathrm{~h}$ and filtered with $0.45 \mu \mathrm{m}$ syringe filter (Whatman). Target cells were incubated with the retrovirus-containing media with $8 \mu \mathrm{g} /$ $\mathrm{ml}$ polybrene (Millipore) and selected with puromycin $(1 \mu \mathrm{g} / \mathrm{ml})$.

\section{Detection of Keap1 modified by 4-OHE 2}

The BPM-labeling assay was conducted to determine the modified Keap1 thiol groups after exposure to 4-OHE based on the protocol described by Abiko et al. [49]. In the cell-free system, recombinant human Keap1 protein was reacted with $4-\mathrm{OHE}_{2}(20 \mu \mathrm{M})$ for $30 \mathrm{~min}$ at $25^{\circ} \mathrm{C}$ in $20 \mathrm{mM}$ Tris- $\mathrm{HCl}(\mathrm{pH} 8.5)$, followed by incubation with $50 \mu \mathrm{M} \mathrm{BPM}$ for $30 \mathrm{~min}$ at $37^{\circ} \mathrm{C}$ and the resulting protein was subjected to Western blot analysis. In another experiment, the same assay was conducted with MCF-10A cells expressing Keap1 WT. In brief, cells were washed with PBS and lysed with RIPA buffer $(50 \mathrm{mM}$ Tris- $\mathrm{HCl}$, pH 8; $0.1 \%$ SDS; $150 \mathrm{mM} \mathrm{NaCl} ; 1 \% \mathrm{NP}-40$; and $0.5 \%$ deoxycholic acid). The cell lysates were centrifuged, and the supernatant was incubated with $100 \mu \mathrm{M}$ $\mathrm{BPM}$ for $30 \mathrm{~min}$ at $37^{\circ} \mathrm{C}$. The resulting lysates were immunoprecipitated by using avidin-agarose overnight at $4^{\circ} \mathrm{C}$. After being washed, the precipitated proteins were eluted and analyzed by Western blot analysis with antiKeap1 antibody. 


\section{Enzymatic in-gel digestion}

Briefly, protein samples isolated from DMSO or 4-OHE 2 -treated MCF-10A-Keap1 WT cells were loaded on $4-12 \%$ gradient Novex Bis-Tris gel and the gel was stained with GelCode ${ }^{\circledR}$ Blue Stain Reagent (Thermo scientific). For the alkylation of the separated proteins, $55 \mathrm{mM}$ iodoacetamide was added and incubated for $30 \mathrm{~min}$ in the dark at room temperature. The alkylated protein samples were digested using trypsin (Promega) overnight at $37^{\circ} \mathrm{C}$ and the digested peptides were extracted with $5 \%$ formic acid in $50 \%$ acetonitrile solution. The supernatants were collected and dried with Speed Vac (Thermo Scientific). The samples resuspended in $0.1 \%$ formic acid were purified and concentrated using C18 ZipTips (Millipore) before mass spectrometry (MS).

\section{Analysis by nano-liquid chromatography- electrospray ionization-tandem mass spectrometry (LC-ESI-MS/MS)}

The tryptic peptides were analyzed using an LTQ (Thermo Finnigan) ion trap equipped with a nano-ESI source in the positive ion mode. Peptides were injected onto a homemade $\mathrm{C} 18$ packed reversed phase column $(12 \mathrm{~cm} \times 75 \mu \mathrm{m})$ and were eluted with a linear gradient from 3 to $50 \%$ solvent B $(0.1 \%$ formic acid in acetonitrile) at a flow rate of $200 \mathrm{~nL} / \mathrm{min}$. The electrospray voltage and the threshold for switching MS to MS/MS were set to $1.95 \mathrm{kV}$ and 500 , respectively. The normalized collision energy was $35 \%$ of the main RF amplitude for MS/MS. All spectra were acquired in a data-dependent scan. Five most intense peaks from the full MS scan were fragmentized. The following parameters were used: repeat count for dynamic exclusion $=1$, repeat duration $=30 \mathrm{~s}$, dynamic exclusion duration $=180 \mathrm{~s}$, exclusion mass $=1.5 \mathrm{Da}$, and the size of the dynamic exclusion list $=50$.

\section{Tumor growth in a xenograft model}

Female BALB/c (nu/nu) athymic nude mice, 6 weeks of age, were purchased from Charles River Laboratories. All animal works were approved by the Seoul National University Ethics Research Board. MDA-MB-231 cells $\left(3 \times 10^{6}\right.$ in $100 \mu \mathrm{l}$ PBS plus $100 \mu 1$ matrigel) were injected subcutaneously into the mammary fatpad regions. After 5 days of implantation, mice were separated in groups of six animals and were subcutaneously treated with vehicle, ZnPP $(10 \mu \mathrm{mol} /$ $\mathrm{kg}$ of body weight dissolved in $0.1 \mathrm{~N} \mathrm{NaOH}$ in PBS, $\mathrm{pH} 7.5), 4-\mathrm{OHE}_{2}(0.3 \mu \mathrm{g} / 0.1 \mathrm{ml} / \mathrm{mouse})$ alone or together with $\mathrm{ZnPP}$, daily for 3 weeks. Tumor volume $(0.52 \times$ length $\times$ width $^{2}$ ) and body weight were measured three times a week.

\section{Immunohistochemical analysis}

Slides using $4 \mu \mathrm{m}$ sections of formalin-fixed and paraffin-embedded xenograft tumors were prepared for immunohistochemical analysis as described previously [50]. Slides were incubated separately with primary antibodies for CA 15-3 (1:200), PCNA (1:500), or COX-2 (1:500) and developed using the anti-rabbit or anti-mouse horseradish peroxidase Envision System (DAKO). The counterstaining was done using Mayer's hematoxylin.

\section{Data analysis}

The acquired LC-ESI-MS/MS fragment spectra were searched in the BioWorksBrowser ${ }^{\mathrm{TM}}$ (version Rev. 3.3.1 SP1, Thermo Scientific) with the SEQUEST search engines against the data in FASTA format generated from Keap1 (NCBI accession number NM_203500.1). The conditions for the search were as follows; trypsin as enzyme specificity, a permissible level for two missed cleavages, peptide tolerance; $\pm 2 \mathrm{amu}$, a mass error of $\pm 1 \mathrm{amu}$ on fragment ions and variable modifications of carbamidomethylation of cysteine $(+57 \quad \mathrm{Da})$, oxidation of methionine $(+16 \mathrm{Da})$ and $4-\mathrm{OHE}_{2}$-induced modification of cysteine $(+287.15 \mathrm{Da})$ residues.

\section{Statistical evaluation}

Data were expressed as the mean $\pm \mathrm{SD}$ of the results obtained from at least three independent experiments. Statistical significance of the obtained data was determined by conducting Student's $t$-test, and a $p$-value of less than 0.01 was considered to be statistically significant.

\section{ACKNOWLEDGMENTS}

The authors thank Dr. Jeffery Johnson (University of Wisconsin, Madison, USA) for providing Nrf2 wild type $\left(\mathrm{Nrf}^{++/}\right)$and Nrf2-null $\left(\mathrm{Nrf2}^{---}\right)$mice. The authors also thank Dr. Jozef Dulak (Jagiellonian University, Krakow, Poland) for providing HO-1 plasmid.

\section{CONFLICTS OF INTEREST}

No potential conflicts of interest were disclosed.

\section{GRANT SUPPORT}

This work was supported by the Global Core Research Center (GCRC) grant (NRF-2011-003-0001) from the National Research Foundation (NRF), Ministry of Science, ICT and Future Planning, Republic of Korea. 


\section{REFERENCES}

1. Gaikwad NW, Yang L, Muti P, Meza JL, Pruthi S, Ingle JN, Rogan EG, Cavalieri EL. The molecular etiology of breast cancer: evidence from biomarkers of risk. Int J Cancer. 2008; 122:1949-1957.

2. Castagnetta LA, Granata OM, Traina A, Ravazzolo B, Amoroso M, Miele M, Bellavia V, Agostara B, Carruba G. Tissue content of hydroxyestrogens in relation to survival of breast cancer patients. Clin Cancer Res. 2002; 8:3146-3155.

3. Liehr JG, Ricci MJ. 4-Hydroxylation of estrogens as marker of human mammary tumors. Proc Natl Acad Sci U S A. 1996; 93:3294-3296.

4. Rogan EG, Badawi AF, Devanesan PD, Meza JL, Edney JA, West WW, Higginbotham SM, Cavalieri EL. Relative imbalances in estrogen metabolism and conjugation in breast tissue of women with carcinoma: potential biomarkers of susceptibility to cancer. Carcinogenesis. 2003; 24:697-702.

5. Cavalieri E, Chakravarti D, Guttenplan J, Hart E, Ingle J, Jankowiak R, Muti P, Rogan E, Russo J, Santen R, Sutter T. Catechol estrogen quinones as initiators of breast and other human cancers: implications for biomarkers of susceptibility and cancer prevention. Biochim Biophys Acta. 2006; 1766:63-78.

6. Cavalieri EL, Stack DE, Devanesan PD, Todorovic R, Dwivedy I, Higginbotham S, Johansson SL, Patil KD, Gross ML, Gooden JK, Ramanathan R, Cerny RL, Rogan EG. Molecular origin of cancer: catechol estrogen-3,4quinones as endogenous tumor initiators. Proc Natl Acad Sci U S A. 1997; 94:10937-10942.

7. Mense SM, Singh B, Remotti F, Liu X, Bhat HK. Vitamin $\mathrm{C}$ and alpha-naphthoflavone prevent estrogen-induced mammary tumors and decrease oxidative stress in female ACI rats. Carcinogenesis. 2009; 30:1202-1208.

8. Huang J, Sun J, Chen Y, Song Y, Dong L, Zhan Q, Zhang R, Abliz Z. Analysis of multiplex endogenous estrogen metabolites in human urine using ultra-fast liquid chromatography-tandem mass spectrometry: a case study for breast cancer. Analytica chimica acta. 2012; 711:60-68.

9. Park SA, Na HK, Kim EH, Cha YN, Surh YJ. 4-hydroxyestradiol induces anchorage-independent growth of human mammary epithelial cells via activation of IkappaB kinase: potential role of reactive oxygen species. Cancer Res. 2009; 69:2416-2424.

10. Li MH, Jang JH, Na HK, Cha YN, Surh YJ. Carbon monoxide produced by heme oxygenase- 1 in response to nitrosative stress induces expression of glutamate-cysteine ligase in PC12 cells via activation of phosphatidylinositol 3-kinase and Nrf2 signaling. J Biol Chem. 2007; 282:28577-28586.

11. Farombi EO, Surh YJ. Heme oxygenase-1 as a potential therapeutic target for hepatoprotection. J Biochem Mol Biol. 2006; 39:479-491.
12. Surh YJ, Kundu JK, Li MH, Na HK, Cha YN. Role of Nrf2-mediated heme oxygenase-1 upregulation in adaptive survival response to nitrosative stress. Arch Pharm Res. 2009; 32:1163-1176.

13. Was H, Cichon T, Smolarczyk R, Rudnicka D, Stopa M, Chevalier C, Leger JJ, Lackowska B, Grochot A, Bojkowska K, Ratajska A, Kieda C, Szala S, et al. Overexpression of heme oxygenase-1 in murine melanoma: increased proliferation and viability of tumor cells, decreased survival of mice. Am J Pathol. 2006; 169:2181-2198.

14. Loboda A, Jazwa A, Grochot-Przeczek A, Rutkowski AJ, Cisowski J, Agarwal A, Jozkowicz A, Dulak J. Heme oxygenase-1 and the vascular bed: from molecular mechanisms to therapeutic opportunities. Antioxid Redox Signal. 2008; 10:1767-1812.

15. McAllister SC, Hansen SG, Ruhl RA, Raggo CM, DeFilippis VR, Greenspan D, Fruh K, Moses AV. Kaposi sarcoma-associated herpesvirus (KSHV) induces heme oxygenase-1 expression and activity in KSHV-infected endothelial cells. Blood. 2004; 103:3465-3473.

16. Alaoui-Jamali MA, Bismar TA, Gupta A, Szarek WA, Su J, Song W, Xu Y, Xu B, Liu G, Vlahakis JZ, Roman G, Jiao J, Schipper HM. A novel experimental heme oxygenase-1targeted therapy for hormone-refractory prostate cancer. Cancer Res. 2009; 69:8017-8024.

17. Fang J, Sawa T, Akaike T, Akuta T, Sahoo SK, Khaled G, Hamada A, Maeda H. In vivo antitumor activity of pegylated zinc protoporphyrin: targeted inhibition of heme oxygenase in solid tumor. Cancer Res. 2003; 63:3567-3574.

18. Miyake M, Fujimoto K, Anai S, Ohnishi S, Nakai Y, Inoue T, Matsumura Y, Tomioka A, Ikeda T, Okajima E, Tanaka N, Hirao Y. Inhibition of heme oxygenase-1 enhances the cytotoxic effect of gemcitabine in urothelial cancer cells. Anticancer research. 2010; 30:2145-2152.

19. Itoh K, Chiba T, Takahashi S, Ishii T, Igarashi K, Katoh Y, Oyake T, Hayashi N, Satoh K, Hatayama I, Yamamoto M, Nabeshima Y. An Nrf2/small Maf heterodimer mediates the induction of phase II detoxifying enzyme genes through antioxidant response elements. Biochem Biophys Res Commun. 1997; 236:313-322.

20. Itoh K, Wakabayashi N, Katoh Y, Ishii T, Igarashi K, Engel JD, Yamamoto M. Keap1 represses nuclear activation of antioxidant responsive elements by Nrf2 through binding to the amino-terminal Neh2 domain. Genes Dev. 1999; 13:76-86.

21. Satoh T, Lipton SA. Redox regulation of neuronal survival mediated by electrophilic compounds. Trends in neurosciences. 2007; 30:37-45.

22. Satoh T, Kosaka K, Itoh K, Kobayashi A, Yamamoto M, Shimojo Y, Kitajima C, Cui J, Kamins J, Okamoto S, Izumi M, Shirasawa T, Lipton SA, et al. a catechol-type electrophilic compound, protects neurons both in vitro and in vivo through activation of the Keap1/Nrf2 pathway via S-alkylation of targeted cysteines on Keap1. Journal of neurochemistry. 2008; 104:1116-1131. 
23. Sumi D, Numasawa Y, Endo A, Iwamoto N, Kumagai Y. Catechol estrogens mediated activation of Nrf2 through covalent modification of its quinone metabolite to Keap1. J Toxicol Sci. 2009; 34:627-635.

24. Lee JM, Anderson PC, Padgitt JK, Hanson JM, Waters CM, Johnson JA. Nrf2, not the estrogen receptor, mediates catechol estrogen-induced activation of the antioxidant responsive element. Biochimica et biophysica acta. 2003; 1629:92-101.

25. Zhang DD, Hannink M. Distinct cysteine residues in Keap1 are required for Keap1-dependent ubiquitination of $\mathrm{Nrf} 2$ and for stabilization of $\mathrm{Nrf} 2$ by chemopreventive agents and oxidative stress. Mol Cell Biol. 2003; 23:8137-8151.

26. Dinkova-Kostova AT, Holtzclaw WD, Cole RN, Itoh K, Wakabayashi N, Katoh Y, Yamamoto M, Talalay P. Direct evidence that sulfhydryl groups of Keap1 are the sensors regulating induction of phase 2 enzymes that protect against carcinogens and oxidants. Proc Natl Acad Sci U S A. 2002; 99:11908-11913.

27. Ogura T, Tong KI, Mio K, Maruyama Y, Kurokawa H, Sato C, Yamamoto M. Keap1 is a forked-stem dimer structure with two large spheres enclosing the intervening, double glycine repeat, and C-terminal domains. Proc Natl Acad Sci U S A. 2010; 107:2842-2847.

28. Costa C, Soares R, Reis-Filho JS, Leitao D, Amendoeira I, Schmitt FC. Cyclo-oxygenase 2 expression is associated with angiogenesis and lymph node metastasis in human breast cancer. J Clin Pathol. 2002; 55:429-434.

29. Ristimaki A, Sivula A, Lundin J, Lundin M, Salminen T, Haglund C, Joensuu H, Isola J. Prognostic significance of elevated cyclooxygenase-2 expression in breast cancer. Cancer Res. 2002; 62:632-635.

30. Banerjee P, Basu A, Datta D, Gasser M, Waaga-Gasser AM, $\mathrm{Pal} \mathrm{S}$. The heme oxygenase-1 protein is overexpressed in human renal cancer cells following activation of the RasRaf-ERK pathway and mediates anti-apoptotic signal. J Biol Chem. 2011; 286:33580-33590.

31. Berberat PO, Dambrauskas Z, Gulbinas A, Giese T, Giese N, Kunzli B, Autschbach F, Meuer S, Buchler MW, Friess H. Inhibition of heme oxygenase-1 increases responsiveness of pancreatic cancer cells to anticancer treatment. Clin Cancer Res. 2005; 11:3790-3798.

32. Jozkowicz A, Was H, Dulak J. Heme oxygenase-1 in tumors: is it a false friend? Antioxid Redox Signal. 2007; 9:2099-2117.

33. DeNicola GM, Karreth FA, Humpton TJ, Gopinathan A, Wei C, Frese K, Mangal D, Yu KH, Yeo CJ, Calhoun ES, Scrimieri F, Winter JM, Hruban RH, et al. Oncogeneinduced Nrf2 transcription promotes ROS detoxification and tumorigenesis. Nature. 2011; 475:106-109.

34. Miyake M, Fujimoto K, Anai S, Ohnishi S, Kuwada M, Nakai Y, Inoue T, Matsumura Y, Tomioka A, Ikeda T, Tanaka N, Hirao Y. Heme oxygenase-1 promotes angiogenesis in urothelial carcinoma of the urinary bladder. Oncol Rep. 2011; 25:653-660.
35. Tan Q, Wang H, Hu Y, Hu M, Li X, Aodengqimuge, Ma Y, Wei C, Song L. Src/STAT3-dependent heme oxygenase-1 induction mediates chemoresistance of breast cancer cells to doxorubicin by promoting autophagy. Cancer science. 2015.

36. Kim DH, Kim JH, Kim EH, Na HK, Cha YN, Chung JH, Surh YJ. 15-Deoxy-Delta12,14-prostaglandin J2 upregulates the expression of heme oxygenase-1 and subsequently matrix metalloproteinase-1 in human breast cancer cells: possible roles of iron and ROS. Carcinogenesis. 2009; 30:645-654.

37. Marinissen MJ, Tanos $\mathrm{T}$, Bolos $\mathrm{M}$, de Sagarra MR, Coso OA, Cuadrado A. Inhibition of heme oxygenase-1 interferes with the transforming activity of the Kaposi sarcoma herpesvirus-encoded $\mathrm{G}$ protein-coupled receptor. J Biol Chem. 2006; 281:11332-11346.

38. Fang J, Sawa T, Akaike T, Greish K, Maeda H. Enhancement of chemotherapeutic response of tumor cells by a heme oxygenase inhibitor, pegylated zinc protoporphyrin. Int $\mathrm{J}$ Cancer. 2004; 109:1-8.

39. Wakabayashi N, Dinkova-Kostova AT, Holtzclaw WD, Kang MI, Kobayashi A, Yamamoto M, Kensler TW, Talalay P. Protection against electrophile and oxidant stress by induction of the phase 2 response: fate of cysteines of the Keap1 sensor modified by inducers. Proc Natl Acad Sci U S A. 2004; 101:2040-2045.

40. $\mathrm{Hu} \mathrm{C}$, Eggler AL, Mesecar AD, van Breemen RB. Modification of keap1 cysteine residues by sulforaphane. Chem Res Toxicol. 2011; 24:515-521.

41. Kobayashi A, Kang MI, Watai Y, Tong KI, Shibata T, Uchida K, Yamamoto M. Oxidative and electrophilic stresses activate Nrf2 through inhibition of ubiquitination activity of Keap1. Mol Cell Biol. 2006; 26:221-229.

42. Tong KI, Katoh Y, Kusunoki H, Itoh K, Tanaka T, Yamamoto M. Keap1 recruits Neh2 through binding to ETGE and DLG motifs: characterization of the two-site molecular recognition model. Mol Cell Biol. 2006; 26:2887-2900.

43. Zipper LM, Mulcahy RT. Erk activation is required for Nrf2 nuclear localization during pyrrolidine dithiocarbamate induction of glutamate cysteine ligase modulatory gene expression in HepG2 cells. Toxicol Sci. 2003; 73:124-134.

44. Yu R, Chen C, Mo YY, Hebbar V, Owuor ED, Tan TH, Kong AN. Activation of mitogen-activated protein kinase pathways induces antioxidant response element-mediated gene expression via a Nrf2-dependent mechanism. J Biol Chem. 2000; 275:39907-39913.

45. Kong AN, Owuor E, Yu R, Hebbar V, Chen C, Hu R, Mandlekar S. Induction of xenobiotic enzymes by the MAP kinase pathway and the antioxidant or electrophile response element (ARE/EpRE). Drug Metab Rev. 2001; 33:255-271.

46. Naughton P, Foresti R, Bains SK, Hoque M, Green CJ, Motterlini R. Induction of heme oxygenase 1 by nitrosative stress. A role for nitroxyl anion. J Biol Chem. 2002; 277:40666-40674.

47. Srisook K, Cha YN. Super-induction of HO-1 in macrophages stimulated with lipopolysaccharide by prior 
depletion of glutathione decreases iNOS expression and NO production. Nitric Oxide. 2005; 12:70-79.

48. Stewart WC, Pearcy LA, Floyd ZE, Stephens JM. STAT5A expression in Swiss 3T3 cells promotes adipogenesis in vivo in an athymic mice model system. Obesity. 2011; 19:1731-1734.

49. Abiko Y, Miura T, Phuc BH, Shinkai Y, Kumagai Y. Participation of covalent modification of Keap1 in the activation of Nrf2 by tert-butylbenzoquinone, an electrophilic metabolite of butylated hydroxyanisole. Toxicol Appl Pharmacol. 2011; 255:32-39.
50. Kundu JK, Shin YK, Kim SH, Surh YJ. Resveratrol inhibits phorbol ester-induced expression of COX-2 and activation of NF-kappaB in mouse skin by blocking IkappaB kinase activity. Carcinogenesis. 2006; 27:1465-1474. 